\title{
Induction of Micronuclei, Cellular Stress Response, and DNA Strand Breakage in Two Common Fish Species From Rivers and Reservoirs in Ilorin, Nigeria.
}

Abass Toba Anifowoshe ( $\square$ anifowoshe.at@unilorin.edu.ng )

University of Ilorin

Segun Olayinka Oladipo

Kwara State University https://orcid.org/0000-0001-7702-9491

Arinola N Oyinloye

University of llorin

Augusta Opute

University of llorin

Edward Odofin

University of llorin

Omotola Aiki

University of llorin

Moshood Y Abdulrahim

University of llorin

Kehinde Monica Akinseye

University of Kansas

Saratu lyabode Abdulkareem

University of llorin

Oluyinka A. lyiola

University of llorin

\section{Research Article}

Keywords: Rivers, Reservoirs, Genotoxicity, Oxidative Stress, Tilapia zillii, Clarias gariepinus

Posted Date: August 9th, 2021

DOl: https://doi.org/10.21203/rs.3.rs-699545/v1

License: (c) (1) This work is licensed under a Creative Commons Attribution 4.0 International License.

Read Full License 
Page 2/24 


\section{Abstract}

Indiscriminate discharge of home, agricultural, and industrial wastes into water bodies, most rivers and reservoirs around the world are becoming polluted. The ecotoxicological potential of this in fish species gathered from important reservoirs and rivers in llorin, Nigeria, was explored in this study. Unilorin reservoir, Asa reservoir, Apodu reservoir, Asa river (Unity), and Asa river (Unity) water samples were collected and physicochemical characteristics were investigated at five distinct sites: Unilorin reservoir, Asa reservoir, Apodu reservoir, Asa river (Unity), and Asa river (Unity) (Harmony). In Tilapia zillii and Clarias gariepinus, we measured serum biochemical (AST, ALT, ALP, serum ALB), histopathological (gills, lungs), and serum antioxidant enzyme responses (SOD, CAT, GPx, GR, GST) as a biomarker for oxidative stress, while micronucleus and comet assays were used to detect DNA damage. Except for DO, which was very low in the two rivers, the physicochemical parameters and heavy metals evaluated in the five separate water bodies were within the allowed levels of the NSDWQ and WHO standard for drinking water. In comparison to the Unilorin, Apodu, and Asa reservoirs, a slight increase in $\mathrm{Pb}$ was observed across the five sampling sites, which could contribute to increased biochemical and haematological profiles, histopathological lesions in the gill and lungs, inductions of MN, NA, and DNA single strand break in T. zillii and $C$. gariepinus collected from Asa rivers. This could be due to the indiscriminate dumping of effluents from adjacent industries, agricultural wastes, and household wastes into rivers.

\subsection{Introduction}

Water is a universal solvent that can dissolve a wide range of compounds to varied degrees. It is a priceless resource since it provides vital support to all types of plants and wildlife. Reservoirs and rivers are valuable biological resources that serve a variety of human requirements, including water conservation (domestic irrigation water supply), flood management, and hydroelectric power generation [1] Water pollution is widely acknowledged as a potential threat to both human and other animal populations that interact with the aquatic environment, resulting in a progressive deterioration of the water body's quality $[2,3,4]$. Water conservation has become a challenge due to pollution. This could be due to the daily input of contaminants from home, agricultural, and/or industrial wastes, all of which harm fish $[3,5]$.

Fish are ecologically important and commercially valuable in Nigeria's and other countries' fishing industries [6, 7]. Clarias gariepinus and Tilapia zillii, for example, are regularly and widely grown in ponds, and they also exist naturally in Nigerian fresh water. As a result, changes in the aquatic environment as well as physic chemical alterations have a significant impact on fish physiology [8]. Because fish absorb pollutants directly from contaminated water, their physiological stress responses are extremely comparable to those of mammals $[4,9]$. Because of their ability to digest and store toxins in water in their numerous organs, fish have also been acknowledged to be a viable choice of animal for evaluating hazardous potential of contaminants (Martin and Costa 2015). They also respond quickly to low concentrations of toxicants, and their responses are similar to those of vertebrates, as fish have 
antioxidant enzymes that are similar to those found in vertebrates and are utilised to counteract the detrimental effects of reactive oxygen species (ROS) [10, 11].

There are various factors that influence water quality, but most past studies on the subject have focused on heavy metals. Variations in Biochemical Oxygen Demand (BOD), Chemical Oxygen Demand (COD), and Dissolved Oxygen (DO) in rivers, as well as the harmful consequences they may have on aquatic life, are underreported, particularly in Nigeria. BOD is the quantity of oxygen taken up by microorganisms living on organic compounds present in the sample (e.g. water or sludge) when incubated at a specific temperature (typically 20oC) for a set period of time (usually 5 days, BOD5) [12]. BOD is an indicator of water pollution since it offers information about the readily biodegradable percentage of the organic load in water. If BOD 5 is greater than $5 \mathrm{mg} / \mathrm{L}$, the water is considered contaminated. The amount of oxygen equivalent of organic matter in a water sample is referred to as COD. It's a common metric for determining the susceptibility of organic and inorganic components in municipal, agricultural, and/or industrial wastes to oxidation. Higher COD values indicate that there is more oxidizable organic material in the sample, lowering DO levels. Anaerobic conditions can result from a decrease in DO, which is harmful to higher aquatic life forms. Hypoxia in water bodies has been shown to enhance ROS production and block the intracellular antioxidant system in aquatic animals, leading to physiological abnormalities and mortality [13].

Asa, Oyun, and Apodu reservoirs, as well as associated water bodies, support a diverse range of fish species and provide the majority of water consumed in Ilorin city, University of Ilorin, and Malete town in Kwara state $[1,7,14]$. Fresh fish and fish items were also provided to the public via its resources. Industrial, agricultural, and home waste discharges and practises, on the other hand, are carried out along the river's bank. These discharges pollute the water and have a negative impact on the recipient environment's biological equilibrium $[3,4,15,16,17]$

The purpose of this study is to provide current information on the genotoxic status of major water bodies in Kwara State, Nigeria, by investigating the physicochemical parameters of the waterbodies, tissue lesions, oxidative stress, and antioxidant response in selected fish species, and assessing the level of genotoxic damage induced in selected fish collected from five different waterbodies.

\section{0 Material And Methods}

\subsection{Study Location}

We gathered fish from five different locations in this study, including Asa reservoir (ARe), Unilorin reservoir (URe), Apodu reservoir (APRe), Asa river (Unity) (ARiU), and Asa river (Harmony) (ARiH), as shown in figure 1.

The Asa reservoir is located 5 kilometres south of llorin, across the Asa River, between latitudes 8025 and $8027 \mathrm{~N}$ and longitudes 4032 and 4034E. The reservoir was built between May 1975 and January 1977 with the goal of addressing the ever-increasing need for drinking water, agriculture, and a source of 
revenue through commercial fishing for the rapidly growing population of llorin, the state capital of Kwara state. The rivers Iwonte, Jia, and Segbekuke are the main tributaries. With a maximum length of 20 kilometres, a breadth of 7 kilometres, and a depth of 13 metres, the reservoir is unusually huge and wide, with a storage capacity of around 43 million cubic metres [14].

The University of llorin reservoir is located in the western portion of Central Nigeria, bounded by longitudes $4040^{\prime} 52^{\prime \prime}$ to $4041^{\prime} 0 " \mathrm{E}$ and latitudes $8027^{\prime} 5^{\prime \prime}$ to 8 o28' $5 " \mathrm{~N}$ in the llorin south local government of Kwara state. URe was founded in 1975, and physical construction of the structures began in 1979 . Between 2015 and 2016, it was restored to a depth of around 5m and a submerged area of roughly 650 $\mathrm{km} 2$. The dam's principal aim is to provide water to the university villages for drinking and irrigation. Because no industry is located along its path, the water rarely receives waste.

Apodu reservoir is located in Apodu hamlet, some 7 kilometres from Malete Town in Kwara State's Moro local government region. The dam was built in 1980, and the re-impoundment was completed in 2016 . It is located between longitudes $8^{\circ} 45^{\prime} 25.9^{\prime \prime} \mathrm{N}$ and $45^{\prime} 27.7^{\prime \prime} \mathrm{N}$, and latitudes $4^{\circ} 27^{\prime} 41.4^{\prime \prime} \mathrm{E}$ and $4^{\circ} 27^{\prime} 35.5^{\prime \prime} \mathrm{E}$, with a length of 560 metres and a width of 400 metres, and a depth of 8.2 metres, with a surface area of around 15 hectares. It has two seasons: a dry season during which the water flow rate declines and a rainy season during which the water flow rate remains constant. It is located in Nigeria's Guinea Savannah region. The reservoir's principal purpose is to supply water for drinking and agriculture to the surrounding villages $[3,7,18]$.

With coordinates of $8^{\circ} 28^{\prime} 0^{\prime \prime}-8^{\circ} 31^{\prime \prime} \mathrm{N}$ and $4^{\circ} 32^{\prime} 0^{\prime \prime}-4^{\circ} 34^{\prime \prime} \mathrm{E}$, the Asa river is one of the major rivers in llorin Kwara state. The river is home to a number of businesses, including Dangote, Coca-Cola, the pharmaceutical, and detergent sectors. Near the river, there are a few small agricultural enterprises such as Ugwu and cassava plantations. The dumping of garbage, sewage disposal, and indiscriminate discharge of effluents/chemicals into the river's body is frequent, making the water appear unsafe for drinking and household purposes [19].

$\mathrm{ARiH}$ is a river segment with coordinates of $8^{\circ} 30^{\prime} 0^{\prime \prime}-8^{\circ} 32^{\prime \prime} \mathrm{N}$ and $4^{\circ} 33^{\prime} 0^{\prime \prime}-4^{\circ} 34^{\prime \prime} \mathrm{E}$ along the Asa River. It is located in llorin's Harmony Estate, with very little garbage entering the waterbody.

\subsection{Samples Collection}

In the early hours of the day, two separate fish species, Tilapia zillii and Clarias gariepinus, were gathered from the five sites: Unilorin reservoir, Apodu reservoir, Asa reservoir, Asa river (unity), and Asa river (Harmony) (6:00-8:30am). They were caught with cast nets, gill nets, and baskets by fishermen. The fish were sorted and identified at the species level using the methods of [20], as well as the assistance of a fish taxonomist. The two most common fish species captured at the various sites were T. zillii and $C$. gariepinus, however, T. zillii specimens were in plenty and were used primarily in our experiment.

The sampled fish were delivered to the Department of Zoology, University of Ilorin, Ilorin, Nigeria, in transparent 50-L plastic aquaria with net cover (to enable ventilation and prevent the fish from jumping 
out). Before blood was collected through the tail area or by caudal vein puncture for analysis, $1 \%$ of ethyl alcohol was used for sedation and the fish were allowed to recuperate from stress. Our investigations used two separate fish species (both T. zilli and C. gariepinus) ( $n=5$ per site) for each analysis. This was done three times. Temperature, $\mathrm{pH}$, electrical conductivity, dissolved oxygen (DO), total dissolved solids (TDS), total suspended solids (TSS), biochemical oxygen demand (BOD), chemical oxygen demand (COD), and heavy metals were all measured in water samples taken from reservoirs and rivers. A Hanna portable waterproof tester, model HI 98129, was used to measure water parameters. A Hanna multiparameter bench photometer for laboratories, model HI 83200, and an AAS (Atomic Absorption Spectrophotometer) (model: Buck scientific ACCUS-IS 211) were used to determine the heavy metals.

\subsection{Analysis of oxidative stress and tissue lesions}

To conduct the oxidative stress analysis, blood was drawn from T. zillii $(n=5)$ from each site and stored in EDTA bottles prior to analysis. Dissection and fixation were used to obtain gill and liver tissue samples for lesion examination. These tissue samples were fixed for a day ( 24 hours) in buffered formal saline and then processed for paraffin tissue embedding using the procedure of [21]. The organ slices were stained with hematoxylin and eosin $(H \& E)$ and viewed using an Olympus light microscope according to [22].

\subsection{Haematological Investigation}

Blood was analysed using the methods outlined by $[23,24]$. Blood samples were collected from the fish at several sampling locations and sent to the lab for analysis, including red blood cell (RBC) profiles, white blood cell (WBC) profiles, and platelet profiles.

\subsection{Antioxidant Enzyme}

The activity of Glutathione S-transferase (GST) was measured using 1 chloro 2, 4 dinitrobenzene as a substrate [25]. Using an extinction coefficient of $9.6 \mathrm{mM}-1 \mathrm{~cm}-1$, the specific activity of glutathione $S-$ transferase was expressed as nmoles of GSH-CDNB conjugate formed $/ \mathrm{min} / \mathrm{mg}$ protein. The catalase activity (CAT) assay based on the breakdown of $\mathrm{H} 2 \mathrm{O} 2$, in which the absorbance was measured at $240 \mathrm{~nm}$ $\left(\mathrm{pH} 7.0,28^{\circ} \mathrm{C}\right)$ and expressed as unit/mg protein.

The activity of superoxide dismutase (SOD) was measured spectrophotometrically at $420 \mathrm{~nm}$ and expressed as a unit/mg protein using the [26] method, which relies on the autooxidation of adrenalin due to the presence of superoxide anion. The assay for glutathione peroxidase was performed using [27] technique. To a combination containing $0.2 \mathrm{~mL}$ of buffer, $0.2 \mathrm{~mL}$ of EDTA, and $0.1 \mathrm{~mL}$ of sodium azide, around $0.2 \mathrm{~mL}$ of tissue homogenate was added. After good mixing, $0.1 \mathrm{~mL}$ reduced glutathione and $0.1 \mathrm{~mL}$ hydrogen peroxide were added, and the mixture was incubated for 10 minutes in a water bath at $37^{\circ} \mathrm{C}$. After the incubation period, $0.5 \mathrm{~mL}$ of $10 \%$ TCA was added and centrifuged for 5 minutes at 10000 $\mathrm{rpm}$. In a separate test tube, $1.0 \mathrm{~mL}$ of the supernatant was added to $2.0 \mathrm{~mL}$ Tris buffer and 50 I DTNB. 
The OD was measured at $412 \mathrm{~nm}$ right away. While the activity of glutathione reductase (GR, EC 1.6.4.2) was measured according to [28].

\subsection{Micronucleus Assay}

Using a $2 \mathrm{~mL}$ syringe and needle, blood was obtained from the caudal area of the two fish species (T. zillii and C. gariepinus) [ $n=5$ per site]. The needle was placed ventrally into the caudal portion of the fish's body until it pricked the vertebral column, then moved out a little to allow blood to flow into the syringe. A drop of blood was immediately placed on a clean, grease-free microscope slide to form a thin blood smear after the dispenser drew around $0.5 \mathrm{ml}$ of blood. In a dust-free environment, the smeared slides were allowed to air dry overnight. The air-dried slides were fixated in $70 \%$ absolute methanol for 20 minutes before being air-dried overnight. The slide was then stained with $10 \%$ Maygrunwald, cleaned with distilled water, and air dried overnight after drying. After that, the glass slide was stained with $5 \%$ giemsa, rinsed with distilled water, and dried. Under a light microscope, the dried slide was scored by counting a total of 2000 erythrocytes, which were then analysed with oil immersion at $1000 \mathrm{X}$ magnification for micronucleus $(\mathrm{MN})$ and nuclear abnormalities (NA) as cytogenotoxicity biomarkers [29, 30].

\subsection{Assay for Comet}

The first/base layer was generated by coating totally frosted slides with 1 percent normal-melting-pointagarose overnight. The second layer consisted of $75 \mathrm{I}$ of 0.7 percent low-melting-point agarose (LMA) and $25 \mathrm{I}$ of lymphocyte suspension. The slides were immediately covered with cover slips and refrigerated on ice for 10 minutes to harden the agarose. The cover slips were removed, and a third layer of $90 \mathrm{I} 0.5$ percent LMA was applied, followed by the cover slips being reinstalled and the agarose being allowed to harden for 10 minutes over ice. Triplicates of each sample were taken. For 2 hours at $4^{\circ} \mathrm{C}$, the slides were submerged in a cold alkaline lysis solution. The slides were then refrigerated in a horizontal electrophoresis tank pre-filled with cold alkaline electrophoresis buffer for 20 minutes at room temperature to loosen the tight double-helical structure of DNA for electrophoresis. The electrophoresis was then carried out in electrophoresis buffer at $4^{\circ} \mathrm{C}$ for 20 minutes at $25 \mathrm{~V}, 300 \mathrm{~mA}$. After electrophoresis, a drop-by-drop application of Tris buffer (0.4 M Tris, $\mathrm{pH}$ 7.5) was used to neutralise excess alkali; the buffer was left on the slides for 5 minutes. This process of neutralisation was carried out three times. After that, the slides were stained for 10 minutes with $80 \mathrm{~L}$ propidium iodide $(2 \mathrm{~g} / \mathrm{ml})$. To avoid further DNA damage, all of the preceding operations were carried out in the dark [31]. A Nikon 90i fluorescence microscope was used to view the comets, and a digital imaging system was used to gather photographs of 100 comets for each concentration. Overlapping cells were not counted. Comet Assay Software Project (CASP, Wroclaw University, Poland) was used to examine all of the comet images, and the tail length (TL), percent tail DNA (\% TDNA), and Olive tail moment (OTM) were recorded to describe DNA damage to lymphoma cells.

2.8 Statistical Analysis 
The micronucleus abnormalities and differences between the test groups were assessed using the SPSS software package version 21.0 (SPSS 21.0). The differences were compared using one-way ANOVA, and the Duncan multiple range test (DMRT) was used to evaluate the degree of statistical significance at $p$ 0.05. The mean standard error was calculated.

\subsection{Results}

3.1 The water samples' physicochemical properties demonstrate a drop in DO and an increase in $\mathrm{Pb}$ when compared to the permitted limit in drinking water.

Except for DO, which was very low in the two rivers, all of the physicochemical parameters and heavy metals evaluated ( $\mathrm{Mn}, \mathrm{Cu}, \mathrm{Ni}, \mathrm{N}, \mathrm{P}, \mathrm{Fe}, \mathrm{Cl}$, and $\mathrm{Ca}$ ) in the five separate water bodies were within the NSDWQ and WHO permitted levels (Table 1). When compared to the limit set by the two organisations, all five locations saw a modest rise in $\mathrm{Pb}(\mathrm{mg} / \mathrm{L})$ (Table 1$)$.

3.2 Biochemical and tissue lesions studies of T. Zilli fish show elevated ALT, AST, ALP, and albumin levels, as well as aberrant gill and liver architecture.

Table 2 shows that the serum ALT, AST, ALP, and albumin enzyme activity of T. zillii in Asa river Unity were significantly higher (p0.05) than in the other four sites. In comparison to the reservoirs, the AST enzyme activity in Asa river Unity and Asa river Harmony are higher. Similarly, when compared to other sites, the ALT of the Asa River Unity and the Apodu Reservoir indicate higher activity.

Figure 2I shows a photomicrograph of $T$. zillii gills taken at the sampling sites. A photomicrograph of a $T$. zillii gill from the Unilorin reservoir, showing the highly vascularized gill arch and outgrowing lamellae under extreme magnification. The highly vascularized gill arch and their connecting primary and secondary lamellae are shown at extreme magnification in the Apodu reservoir (B). It looks to be normal, with a lengthy and well-vascularized lamellar system and no signs of pathology. The principal lamellae appear to be short and are supported in the middle by a cartilage with a good vascular supply. T. zillii from the Asa reservoir has a highly vascularized gill arch and outgrowing lamellae, with no evidence of pathological changes (Figure 2I (C). The principal lamellae appear to be short and are supported in the middle by a cartilage with a good vascular supply. Figure 2 l (D) shows a high-power magnification ( $x 400)$ of the gill arch and gill rakes in a photomicrograph of T. zillii gill from Asa river in Unity. The secondary lamella appear to be pathologically altered, as they appear to be degenerating, deformed cartilage with epithelial lining. The gill arch and their neighbouring primary and secondary lamellae are shown in Figure 2I (E), which is a photomicrograph of T. zillii gills from Harmony. It seems deformed, with disruption of gill filaments that appear to be degenerating and twisted, as seen in the gill arch.

Figure 2II (A) shows representative photomicrographs of the liver in the Unilorin reservoir, showing densely displayed hepatocyte nuclei (black arrows) with normal staining features and cellular arrangement. Their general histomorphology appears to be normal, with no obvious pathological changes. In C; T. zillii liver from Asa reservoir, hepatocyte nuclei are densely dispersed (black arrow). The 
micrograph looks to be typical of normal, with normal staining intensity and histoarchitectural presentation. The photomicrograph in $\mathrm{D}$ (Unity) depicts the central vein (black outline) and a high magnification of hepatocytes (black arrow), exhibiting nuclei placement, staining intensity, and overall histomorphological presentation. A standard sized halo spaced centre vein is surrounded by densely scattered hepatocytes in this histomorphological presentation of the liver. The T. zilliii liver in E (Harmony) exhibits thickly scattered hepatocyte nuclei (black arrow). The micrograph looks to be typical of normal, with normal staining intensity and histoarchitectural presentation.

3.3 RBC, WBC, and PLT levels have increased in haematological study.

Table 3 shows the mean value of haematological parameters along with the standard deviation. Table $3 \mathrm{~A}$ shows that RBC (red blood cell), HGB (haemoglobin), MCV (mean corpuscular volume), and MCH (mean corpuscular haemoglobin) in T. zillii from Asa river (Unity) are significantly higher (p0.05) than in other sampling sites. $\mathrm{MCH}$ and $\mathrm{MCHC}$ (mean corpuscular haemoglobin concentration) levels in Asa river fish also increased significantly (Harmony). The changes in HCT (haematocrit) and RDW (red blood cell distribution width) between the 5 sites were minor. There was no significant difference ( $\mathrm{p} 0.05)$ between the 5 sites in WBC profiles (WBC (white blood cell), LYM (lymphocyte), MID (mid-sized cells), and GRAN (granulocyte). When compared to other species, T. zillii near Asa river (Unity) has a considerable rise in GRAN (Table 3B). PLT (platelet), MPV (mean platelet volume), PDW (platelet distribution width), PLCR (platelet larger cell ratio), and PCT (plateletcrit) measurements across the five sites indicate no significant variation (p0.05). However, PLT and PDW in T. zillii at Asa river (Harmony) and PLT and PLCR at Asa river (Unity) increased significantly (Table 3C).

3.4 The release of antioxidants indicates that the cells are under oxidative stress.

The order of antioxidant enzyme reactions in T. zillii blood was statistically different (p0.05) across the five sampling sites; SOD responses were highest in Unity river, followed by Unilorin, Harmony, Apodu, and lowest in Asa reservoir; CAT responses were significantly highest in Unity, followed by Harmony, Unilorin, Apodu, and least significant in Asa reservoir; GPx responses were greatly induced in Apodu, followed by Asa reservoir, Unity, Harmony, and lowest in Unilorin; GR responses were significantly Unilorin; GR responses were significantly Unilorin; GR responses were significantly (Table 4; Figure 3).

Micronuclei (MN) increase, nuclear abnormalities (NA), and DNA single strand break are all signs that the fish are suffering from DNA damage. The peripheral blood erythrocytes of two fish species (T. zillii and C. gariepinus) obtained at various locations demonstrate induction of micronuclei $(\mathrm{MN})$ and other nuclear abnormalities (NA), such as binucleated, nuclear bud, notched, lobed, and blebbed. With each of the two fish species obtained, site comparisons were made(ARiU> (ARiH) $\geq($ APRe) $\geq($ URe) $>($ ARe) (Figure 4b). In this investigation, it was discovered that T. zillii had a higher amount of NA than C. gariepinus (Figure 4b).

As illustrated in Figure 5a and b, the level of DNA damage detected in the peripheral lymphocytes of fish collected at various places was assessed using the alkaline comet assay with parameters such as percent tail DNA, olive tail moment, and tail length. The blood cells of fish obtained from the Asa river 
Unity had the highest degree of DNA single strand break. In fish gathered at Unilorin and Asa reservoirs, there was no significant variation in the level of DNA single strand break. When comparing the two fish species, the DNA damage reported in T. zillii is higher than in C. gariepinus. In comparison to the selected reservoirs, DNA damage was found to be higher in fish species taken from river sites. The level of DNA damage in the Apodu reservoir has been found to be higher in reservoir sites. The level of DNA damage at each of the five locations is as follows: >Apodu,> Asa river harmony,>Unilorin >Asa reservoir.

\subsection{Discussion}

The Nigerian Standard for Water Quality is the legally recognized standard for drinking water quality in Nigeria (NSDWQ). This specifies the allowed values (which must not be exceeded) for certain water parameters before it may be regarded safe to drink [32]. Because to indiscriminate discharge of home, agricultural, and industrial pollutants into water bodies, most rivers and reservoirs around the world are polluted. These wastes are hazardous, and they have the potential to change the ecosystem and genetic makeup of aquatic organisms. The physico-chemical characteristics in the rivers (Asa river Unity \& Harmony) show a low level of DO and a minor increase in BOD, indicating hypoxia and a slight nitrate content due to runoff from agricultural fields in the vicinity that utilize pesticides and fertilizers for farming. Increased Pb, low DO levels in the river, and a modest increase in BOD and COD values obtained from the Asa river in Unity could be due to industrial effluents, home wastes, and runoff from some agricultural operations along the river's edge. This is due to de-oxygenation brought on by the discharge of industrial effluents into the water body. Because it determines the distribution of animals and flora, DO has been recognized as the most essential measure for measuring water quality [33]. Local streams in Uyo, Akwa-lbom state, have also been found to be polluted by home sewage and waste, resulting in low DO and high Nitrate levels, according to our findings [34].

The enzymes ALP, AST, and ALT are produced in the liver, and their presence in the blood signifies liver damage. Significantly higher levels of oxidative enzymes in Asa river Unity indicate fish liver inflammation, damage, stress, and disease, which could be linked to a minor rise in conductivity, BOD, COD, and a fall in DO, which could have put the fish under undue stress. This is consistent with the findings of [35], who found significant levels of AST in examined fish samples as a result of water pollution.

The gills, one of the important organs, are a key target for contaminants since they are in constant touch with the outside world [36]. The histological lesions discovered in the gills, particularly near Asa river Unity and Harmony, suggest that the fish react to hazardous chemicals in the water. According to [37], this could disrupt the blood flow in the gills. The liver, which is most affected by pollutants in the water, is the organ most connected with the detoxification and biotransformation process. The liver histology presentations in the Asa River Unity, Asa River Harmony, and Apodu reservoirs revealed aberrant liver architecture with vacuolation. According to $[15,38]$, this change could be caused by a pollutant in the ecosystem.. 
Blood is a tissue that reacts to changes in our surroundings. It consists of RBCs, WBCs, PLTs, and plasma. They're useful bioindicators for determining water quality [3, 4, 39, 40, 41, 42]. Changes in haematological parameters can be caused by contaminated water. In comparison to other sampling locations, we found a significant increase (p0.05) in RBC, HGB, MCV, MCH, GRAN, PLT, and PLCR in T. zillii from Asa river (Unity). $\mathrm{MCH}, \mathrm{MCHC}, \mathrm{PLT}$, and PDW levels in Asa river fish were likewise significantly higher (Harmony). This finding is consistent with that of [43], who found minor alterations in $\mathrm{HGB}, \mathrm{MCHC}$, and WBC levels, as well as significant changes in RBC, MCV, and $\mathrm{MCH}$ in blood of common carp (Cyprinus carpio) in two lakes in Kosovo. This disparity in RBCs could be related to the rivers' low Do levels (Asa rivers (Unity/Harmony) and a modest increase in $\mathrm{Pb}$. Animal anemia is diagnosed using blood parameters such as $\mathrm{MCV}, \mathrm{MCH}$, and $\mathrm{MCHC}$ [44]. In the event of various anemias, the values of these indicators increase.

Changes in water quality parameters have been linked to the activation of the antioxidant defence system in fish and other aquatic organisms living there, which may further elevate antioxidant responses in these organisms in the presence of environmental pollutants from agricultural, domestic, and industrial sources, as well as landfill leachates, resulting in the production of reactive oxygen species $(\mathrm{ROS})[45,46]$. Although oxidative stress and antioxidant responses have been used as biomarkers to assess the genotoxic potential of rivers in Nigeria such as the Ogun, Eleyele, and Asejiri rivers [47, 48, 49], little is known about the oxidative stress and antioxidant responses of fish in major reservoirs and rivers in Kwara state When there is an imbalance in the level of reactive oxygen species (ROS) and antioxidants in fish, the antioxidant defence system is triggered, and this defence is swiftly activated to checkmate oxidative stress that may be generated by elevated levels of pro-oxidants in the fish [50] (Livingstone 2001). The initial line of defense against oxidative stress is usually SOD and CAT, and their activities are easily evident as an increase in enzyme activity [51]. Antioxidants may be reduced in cells as a result of exposure to environmental contaminants, but antioxidant levels may rise to compensate for the oxidative stress imbalance $[48,49]$. Increased SOD activities in Unity and Harmony rivers could be a reaction to oxidative stress produced by low oxygen levels (low DO and modest increase in Pb), which could lead to hypoxia. Reduced oxygen levels may have triggered the generation of superoxide anions (the most damaging free radicals), which were catalytically scavenged by SOD and converted to $\mathrm{H} 2 \mathrm{O} 2$, a defence readily adopted by the fish's antioxidant enzyme to limit oxygen toxicity. The findings in the SOD activities harmony and Unilorin reservoir are consistent with the findings of $[47,50]$, who link higher SOD concentrations in fish to oxidative stress.

In fish exposed to contaminants, CAT is a key enzyme that works on hydrogen peroxide. CAT, along with SOD, is normally the first line of defence in fish exposed to pollutants, and while CAT levels increase in fish exposed to pollutants, CAT levels have been found to decrease in contaminated water bodies, as reported by [47]. Representative fish species in the Unilorin reservoir and Unity river had lower CAT levels than those in the Harmony river, but the CAT values in the Asa and Apodu reservoirs were not statistically different. Increased generation of ROS is slowly beginning to overpower the CAT defence, which could suggest that the fish is under oxidative stress. The CAT level findings are consistent with those of [48], who found that an increase in ROS generation is associated with lower catalase activity and other 
antioxidant enzymes. Increased CAT activity in the Harmony River is a common response to environmental contaminants, as CAT and SOD are the first line of defence against oxidative stress. The blood of representative fish species from Apodu reservoir had the greatest GPx levels, followed by Asa reservoir and Unity river. GPx activity was reduced in the Asa river (Harmony), with the lowest values found in the Unilorin reservoir. Increased GPx levels show that this enzyme has a preventive and adaptive role against oxidative stress caused by heavy metals or organic contaminants. The increased GPx level backs up the findings of [53], who discovered that fish GPx activity was 1.8-fold greater in contaminated rivers. The lower GPx level could suggest a low amount of pollution in the Unilorin reservoir and a circumstance where the Asa river is self-purifying (Harmony). In order to maintain the GSH/GSSG ratio, GR catalytically reduces oxidised glutathione. GR and GPx operate together because an increased level of GR may indicate oxidative stress, which may necessitate an increase in GPx to offset the stress impact [55]. The highest GR values were found in the blood of representative fish species from Unilorin reservoir, followed by Asa river (Harmony), Apodu reservoir, Asa river (Unity), and Asa reservoir with the lowest GR values. Increased GR may indicate oxidative stress in fish, which is consistent with the findings of [56], who found increased GR in fish exposed to higher levels of pollution. GST levels were found to be lower in the blood of T. zillii from Unilorin reservoir, Asa river (Harmony), Asa river (Unity), Apodu reservoir, and Asa reservoir, and higher in Asa reservoir. The decrease can be linked to an increase in ROS production, and antioxidant levels in cells may be depleted in cells during exposure to environmental contaminants, according to [49]. The degree of DNA damage was then evaluated using two separate tests. When compared to $\mathrm{C}$. gariepinus, the micronucleus test, which is a reliable and sensitive assay that is commonly used as a diagnostic of DNA damage, revealed induction of micronuclei and other nuclear abnormalities in T. zilli at all five sites. Our findings contradict those of [56], who found that the peripheral blood of C. gariepinus was particularly sensitive to the production of $\mathrm{MN}$ when compared to T. zillii, which was sensitive to the creation of MN when compared to two other tilapia species; Oreochromis niloticus, and Oreochromis aureus.

This could be due to the fact that T. zillii has accumulated various metals in its body systems, such as $\mathrm{Pb}$, and it also shows that its genome can withstand cytogenetic damage without apoptosis. The findings support [57] finding that fish living in contaminated waters, such as the ARiU location in our study, have higher micronuclei rates $(\mathrm{MN})$. MN frequencies can change depending on the season, stress, pollutant type, and heavy metals.

The comet assay has been used to evaluate the impact of genotoxic contaminants on DNA integrity with great success. It has several advantages as a tool for genotoxic studies, including the ability to detect genotoxic damage at the single-cell level, suitability for most eukaryotic cell types; only a small number of cells are needed, faster and more sensitive than other available methods for detecting strand breaks, low cost, and the ability to detect early genotoxic exposure response $[58,59]$. In this work, the comet assay in fish was used to assess the genotoxicity of the five sample sites for the first time across all five sites. Because comets might be observed with the same length but varied fluorescence intensities, the percentage tail DNA (percent tail DNA) is the parameter of choice for DNA damage assessment [60]. In 
descending order, Asa river (Unity) >Apodu reservoir> Asa river (Harmony) $>$ Unilorin reservoir $>$ Asa reservoir displays the reservoir with the highest and lowest DNA damage (Asa river (Unity) and Asa reservoir).

The Asa river (upstream), which has extended its path towards the Unity area (mid-stream) and Harmony area (downstream), exhibits a striking pattern. When compared to its courses, the Asa river (upstream) has the least DNA damage (Unity and Harmony rivers). Low DNA damage in the upstream and high DNA damage in the midstream could be linked to the amount of genotoxic chemical exposure. When a pollution gradient exists along the river, the rising amount of genotoxicity in C. gariepinus and T. zillii peripheral erythrocytes is directly linked to the level of pollutant. The trend observed on the Asa water course agrees with [61], who found that DNA damage was highest in the mid-stream (Asara) of the Karai river due to high influx of pollutants from sewage and industries, and DNA damage was lowest in the upstream (Varangerud) due to low pollution levels.

According to [3] the increase (percent tail DNA and tail length) observed in Apodu reservoir compared to the negative control can be attributed to a slight increase in $\mathrm{Pb}$ and nitrate pollution due to sewage disposal and runoff from nearby farms that use pesticides and fertilisers for their farming activities. Exposure to pollutants from diverse sources can have additive, synergistic, or antagonistic interactions with fish [62]. DNA damage can accumulate through an increase in the number of DNA-damaging events or a decrease in DNA repair [62,63]. The Apodu reservoir's results are consistent with those of [64], who found a considerably higher degree of DNA damage in Channa punctatus and Mystus vittatus erythrocytes exposed to contaminated water from the Gomti River in India when compared to baseline values. When compared to the negative control, the Unilorin reservoir contains a low percentage of tail DNA. This is likely due to the fact that it is utilised for leisure activities and the reservoir is not close to residential areas, thus it receives little or no domestic garbage. The only conceivable source of contamination would be runoff during the rainy season or from the reservoir's water channel.

In most of the sampling sites, the results from the combined use of comet test and antioxidant responses to determine genotoxic potential were in accord, but in a few, they differed. Both the comet assay and antioxidant enzyme reactions indicated that the Unity and Harmony rivers were contaminated. This is comparable to the findings of [65], who found that the comet assay and antioxidant enzyme responses matched. The Apodu and Unilorin reservoirs have a little difference. Although DNA damage is modest in the Unilorin reservoir, antioxidant responses were inconsistent, which could imply that the reservoir is likely exposed to minute contaminants that induce these reactions. The antioxidant responses of the Apodu reservoir, which has substantial DNA damage, are mild. This is because, according to the researchers, the comet assay is a more sensitive test than the antioxidant response because it can identify toxins at low doses [62]. As a result, combining the comet assay with antioxidant enzyme responses allows for a more complete picture of a water body's genotoxic condition.

\subsection{Conclusions And Suggestions}


Using various tests and antioxidant enzyme reactions, the cytogenotoxic potential and antioxidant response of five water bodies were studied. The water bodies surveyed were found to be currently polluted, and if anthropogenic activity on these water bodies continue unabated, the ecology and biotic life may deteriorate more quickly than self-purification can repair. It is strongly advised that the government enact legislation to prohibit indiscriminate dumping of rubbish into water bodies, educate the public about the consequences of such activities, and warn people about the dangers of eating infected fish; otherwise, what goes around comes around.

\section{Declarations}

Pre-print Platform Statement: This article has been already submitted to a pre-print platform with DOI: 10.21203/rs.3.rs-172188/v1 and licensing information creativecommons.org/licenses/by/4.0/

Funding: No funding is available.

Conflicts of Interest: There are no conflicts of interest.

Data Availability: The corresponding author can provide data sets generated and/or analysed during the study upon request.

Animal Research (Ethics): Experimental animals were cared for and used in accordance with Nigerian animal welfare laws, guidelines, and policies given by University Ethical Review Committee of the University of Ilorin, llorin, Nigeria

Participant Consent (Ethics): Not applicable

Consent to Publish (Ethics): This does not apply.

Plant Reproducibility: This isn't the case.

Author Contribution: AAT and OSO designed the study; AAT and OSO wrote the paper. AAT, OSO, OAN, OA, OEO, AO, and AYM gathered, stored, and analysed materials in the lab. Technical assistance was provided by AKM, SIA, and IOA for the study. AAT and OSO wrote the first draught of the manuscript, which was then reviewed and edited by AKM, SIA, and IOA. The final manuscript was read and approved by all writers.

\section{References}

[1] Mustapha MK (2010) Fish fauna of oyun reservoir, Offa, Nigeria. Journal of Aquatic Science 25(1):106-114.

[2] Sevensson B, Nilsson A, Jonsson E, Schutz A, Akesson B, Hagmar L (1995) Fish Consumption and exposure to persistent organochlorine compounds, mecury, selenium and methylamines the assessment 
of aquatic pollution. J. Environ. Res. Develop. 8(2): 371-375.

[3] Anifowoshe AT, Oladipo SO, Owolodun OA, Akinseye KM, Olafimihan TF, Sidiq AG (2018) Ecogenotoxicological assessments of some selected fish species from Apodu Reservoir, Malete, North Central, Nigeria. Manila journal of science 11: 1-14.

[4] Anifowoshe AT, Oladipo SO, Adebayo MO, Eboh SO, Abdussalam RA, Adegbenro MA, (2019) Induction of Micronuclei, Base-pair Substitution Mutation and Excision-repair Deficient by Polluted Water from Asa River in Nigeria. Annals of Science and Technology 4 (2): 68-77.

[5] Kushwaha B, Pandey S, Sharma S, Srivastava R, Kumar R, Nagpure NS (2012) In situ assessment of genotoxic and mutagenic potential of polluted river water in Channa punctatus and Mystus vittatus. International Aquatic Research, 4: 16.

[6] Ita EE, Sado EK, Balogun JK, Pandogori A, Ibitoye B (1985) Inventory survey of Nigerian inland waters and their fishery resources. A preliminary checklist of inland water bodies in Nigeria with special reference to Ponds, Lakes Reservoirs and major Rivers. Kainji Lake Research Institute. Technical Report Series No.14

[7] Oladipo SO, Mustapha MK, Suleiman LK, Anifowoshe AT (2018) Fish composition and diversity assessment of Apodu Reservoir, Malete, Nigeria. International Journal of Fisheries and Aquatic Studies 6(2): 89-93.

[8] Musa SO, Omoregie E (1999) Haematological changes in the mud fish, Clarias gariepinus (burchell) exposed to malachite green. Journal of Aquatic Sciences 14: .37- 42

[9] Mishra R, Shukla SP (2003) Endosulfan effects on muscle malate dehydrogenase of fresh water catfish claria batrachus. Ecotoxicology and environmental safety 56: 425-433.

[10] Klobucar GIV, Stambuk A, Mirjana P, Mirela SP, Hackenberger BK, Ketil H (2010) Genotoxicity monitoring of freshwater environments using caged carp (Cyprinus carpio). Ecotoxicology 19: 77-84

[11] Almeida JA, Novelli ELB, Dal Pai Silva M, Alves Junior R (2001) Environmental cadmium exposure and metabolic responses of the Nile tilapia, Oreochromis niloticus. Environmental pollution 114: 169-175

[12] Jouanneau, S., Recoules, L., Durand, M. J., Boukabache, A., Picot, V., Primault, Y., Lakel, A., Sengelin, M., Barillon, B. Thouand, G. (2014). Methods for assessing biochemical oxygen demand (BOD): A review. Water Research, 49, 62-82. doi:10.1016/j.watres.2013.10.066

[13] Pollock MS., Clarke LMJ. Dubé MG (2007). The effects of hypoxia on fishes: from ecological relevance to physiological effects. Environmental Reviews, 15(NA), 1-14. doi:10.1139/a06-006

[14] Omotosho JS (1998) Ichthyofauna diversity of Asa reservoir, llorin, Nigeria. Bioscience Biotechnology Research Communications 10(1): 75-81. 
[15] Oladipo, SO, Adeniyi, T. Anifowoshe, AT. (2020). Histological and Hepatic Enzymes Response of Oreochromis niloticus and Clarias anguillaris to Pollution in Asa River, llorin , Journal of Life and Bio Sciences Research 16 (1): 16-21.

[16] Anifowoshe, AT. Oyebanji, JB, Oladipo, OS, Oyeyemi,FB, Abdulrahim, MY, Abdulkareem, SI Mustapha, MK. (2020) Histological changes, Micronuclei induction and Nuclear abnormalities in the peripheral erythrocytes of Clarias gariepinus (Burchell 1822) exposed to water sample from Apodu Reservoir , Journal of Life and Bio Sciences Research 1 (1) 1-7.

[17] Akinboro, A. Peter, NA, Rufai, MA, Ibrahim, AO. (2021) Evaluation of Asa River Water in Ilorin, Kwara State, Nigeria for Available Pollutants and their Effects on Mitosis and Chromosomes Morphology in Allium cepa Cells. J. Appl. Sci. Environ. Manage. 25 (1) 119-125

[18] Oladipo SO, Sunday OJ, Ogunbiyi, DC (2019) Occurrence and prevalence of parasites associated with Gnathonemus senegalensis in Apodu reservoir, Malete, Nigeria. Sri Lankan J. Biol. 4 (1): 14-23

[19] Kolawole OA, Ajayi KT, Olayemi AB, Okoh Al (2011) Assessment of water quality in Asa River (Nigeria) and its indigenous Clarias gariepinus Fish. International Journal of Environmental Research and Public Health 8(11): 4332-4352.

[20] Idodo-Umeh G. (2003). Freshwater fishes of Nigeria (taxonomy, ecological notes diet and utilization). Idodo Umeh publishes limited, Benin City, Nigeria, 112.

[21] Gobinath J, Ramanibai R (2014) Histopathological studies in the gill, liver and kidney of the freshwater fish LabeoRohita fingerlings. International Journal of Innovative Research in Science, Engineering and Technology 3(3): 10296

[22] Bancroft JD, Gamble H (2008) Theory and practice of histological technique, 6th ed. Philadelphia: Churchill Livingstone/Elsevier, New York. 240p.

[23] Svobodova ZD, Pravda, Palackova J (1991) Unified Methods of Haematological Examination of Fish. Research Institute of Fish Culture and Hydrobiology, Vodnany, Czech Republic, 31pp.

[24] Sovio A, Oikari A (2004) Haematological effect of stress on a teleost. Essex Lucius. J fish Biology 8: $397-411$

[25] Habig WH, Pabst MJ, Jacoby WB (1974) Glutathione-S-transferases. The first enzymatic step in mercapturic acid formation. J. Biol. Chem 249: 7130-7139.

[26] Misra HP (1972). The superoxide anion in antioxidation of epinephrine and simple assay for superoxide dismutase. Journal of biological chemistry 247: 3170-3175.

[27 Paglia DE, Valentine WN (1967) Studies on the quantitative and qualitative characterization of erythrocyte glutathione peroxidase, J. Lab. Clin. Med. Thesis 70: 158-169. 
[28] Glatzle D, Vuilleumier JP, Weber F, Decker K (1974) Glutathione reductase test with whole blood, a convenient procedure for the assessment of the riboflavin status in humans. Experientia 30: 665-667.

[29] Carrasco KR, Tilbury KL, Myers MS (1990) Assessment of the piscine micronucleus test as in situ biological indicator of chemical contaminant effects. Canadian Journal of Fisheries and Aquatic Sciences 47: 2123-2136.

[30] Ergene S, Cavas T, Celik A, Koleli N, Aymak C (2007) Evaluation of river water genotoxicity using piscine micronucleus test. Environmental and Molecular Mutagenesis 48: 421-429.

[31] Bajpayee M, Dhawan A, Parmar D (2009) Comet assay; a reliable tool for the assessment of DNA in different models. Cells Biology and Toxicology 25: 5-32

[32] Ighalo, J. O. Adeniyi, A. G. (2020). A Comprehensive Review of Water Quality Monitoring and Assessment in Nigeria. Chemosphere, 127569. doi:10.1016/j.chemosphere.2020.127569

[33] Morrison HA, Smokorowski KE (2000) The applicability of various frameworks and models for assessing the effects of hydropeaking on the productivity of aquatic ecosystems. Canadian Technical Report of Fisheries and Aquatic Sciences, 2322.

[34] Akpan A.W. (2004). The water quality of some tropical freshwater bodies in Uyo (Nigeria) receiving municipal effluents. slaughter-house washings and agricultural land drainage Environmentalist, 24:49-55

[35] Oshode OA, Bakare AA, Adeogun AO, Efuntoye MO, Suwunmi AA (2008) Ecotoxocological assessment using Clarias gariepinus and microbial characterization of leachate from municipal solid waste landfill. International Journal of Environmental Research 2(4) 391-400

[36] Camargo MM, Martinez CB (2007) Histopathology of gills, kidney and liver of a neotropical fish caged in an urban stream. Neotropical Ichthyology 5(3): 327-336.

[37] Stentiford GD, Longshaw M, Lyons BP, Jones G, Green M, Feist SW (2003). "Histopathological biomarkers in estuarine fish species for the assessment of biological effects of contaminants", Marine Environmental Research 55: 6-14

[38] Oladipo, SO, Anifowoshe, AT., Olafimihan TF. (2020). Assessment of histopathological damages in swiss albino male mice induced by automobile waste leachate, Animal Research International (2018) 15(1): $2944-2949$

[39] Kopp R, Lang Š, Brabec T, Mareš J (2013) The influence of physicochemical parameters of water on plasma indices in brook trout (Salvelinus fontinalis, Mitchill) reared under conditions of intensive aquaculture. Acta Veterinaria Brno 82: 367-374.

[40] Khan AS, Zhou P, Liu X, Li H, Li J, Rehman Z, Ahma J (2015) Response of vitamins A, E, hematological and serum biochemical markers in Crucian carp (Carassius auratus gibelio) exposed to 
environmental Pb2+ and Cd2+. Acta Biochemica Polonica 62: 581- 587.

[41] Parrino V, Cappello T, Costa G, Cannavà, C, Sanfilippo M, Fazio F (2018) Comparative study of haematology of two teleost fish (Mugil cephalus and Carassius auratus) from different environments and feeding habits. The European Zoological Journal 85: 194-200.

[42] Osman GMA, AbouelFadl YK, El Reheem ABMA, Mahmoud MU, Kloas W, Moustafa AM (2018) Blood Biomarkers in Nile tilapia Oreochromis niloticus and African Catfish Clarias gariepinus to Evaluate Water Quality of the River Nile. Journal of fisheries sciences, 12, 001-015.

[43] Sahiti H, Bislimi K, Dalo E, Murati K (2018) Effect of water quality in hematological and biochemical parameters in blood of common carp (Cyprinus carpio) in two lakes of Kosovo. NESciences, 3(3), 323332 DOI: 10.28978/nesciences.468987.

[44] Coles EH (1986) Veterinary Clinical Pathology. W.B. Saunders, Philadelphia, pp 10-42.

[45] Slaninova A, Smutna M, Modra H, Svobodova Z (2009) A review: Oxidative stress in fish induced by pesticides. Neuroendocrinol Lett, 30(Suppl 1), 2-12. PMID: 20027135.

[46] Sevcikova M, Modra H, Slaninova A, Svobodova Z (2011) Metals as a cause of oxidative stress in fish: a review. Veterinarni Medicina 56 (11): 537-546.

[47] Farombi EO, Adelowo OA, Ajimoko YR (2007) Biomarkers of oxidative Stress and Heavy Metal Levels as Indicators of Environmental Pollution in African Cat Fish (Clarias gariepinus) from Nigeria Ogun River. International Journal of Environmental Research and Public Health 4 (2): 158-165.

[48] Arojojoye OA, Adeosun AM (2016a) Effect of environmental pollution on oxidative stress biomarkers in African cat fish (Clarias gariepinus) from Asejire river in Oyo,state. Journal of Environmental and Occupational Science, 5: 4

[49] Arojojoye OA, Nwaechefu 00, Ajiboye JA, Akintunde JK (2016b) Induction of oxidative stress in Clarias gariepinus from Eleyele River in Nigeria. Advances in Environmental Research, 5 (3): 179-187.

[50] Livingstone DR (2001) Contaminant-stimulated Reactive Oxygen Species Production and Oxidative Damage in Aquatic Organisms. Marine Pollution Bulletin 42: 656-666.

[51] McCord JM (1996) Effects of positive iron status at a cellular level. Nutr Rev. 54: 85-8.

[52] Isamah GK, Asagba SO, Coker HA (2000) Comparative Evaluation of the Levels of Some Antioxidant Enzymes and Lipid Peroxidation in Different Fish Species in Two Rivers in the Western Niger Delta. Bulletin of Environmental Contamination and Toxicology 65: 351-356

[53] Lenartova V, Holovska K, Pedrajas JR, Lara EM, Peinado JL, Barea L (1997) Antioxidant and Detoxifying Fish Enzymes Biomarkers of River Pollution. Veterinary Journal 147: 18-30. 
[54] Akpakpan El, Akpanyung EO (2014) Biomarkers of Oxidative Stress and Histopathological Studies in Fish from Ibaka and Ifiayong Rivers, Akwa Ibom State, Nigeria. World Applied Sciences Journal 32 (7): 1209-1218.

[55] Pandey S, Parvez S, Ahamd Ansari R, Ali M, Kaur M, Hayat F (2008) Effects of exposure to multiple trace metals on biochemical, histological and ultrastructural features of gills of a freshwater fish, Channa punctate Bloch. Chemico-Biological Interactions 174(3): 183-192.

[56] Ali FK, El-Shehawi AM, Seehy MA (2008) Micronucleus test in fish genome: A sensitive monitor for aquatic pollution African Journal of Biotechnology 7 (5): 606-612.

[57] Kligerman AD (1982) Fishes as biological detectors of the effects of genotoxic agents. In J. Heddle (Ed.), Mutagenicity: New horizons in genetic toxicology (pp. 435-456). New York: Academic Press.

[58] Dhawan A, Bajpayee M, Parmar D (2009) Comet assay: a reliable tool for the assessment of DNA damage in different models. Cell Biol Toxicol. 25(1):5-32.doi: 10.1007/s10565-008-9072-z

[59] Frenzilli G, Nigro M, Lyons B (2009) The Comet assay for the evaluation of genotoxic impact in aquatic environments. Mutat. Res./Rev. Mutat. Res. 681: 80-92.

[60] Schnurstein A, Braunbeck T (2001). Tail moment versus tail length-application of an in vitro version of the comet assay in biomonitoring for genotoxicity in native surface waters using primary hepatocytes and gill cells from zebrafish (Danio rerio). Ecotoxicol Environ Saf., 49:187-196.

[61] Hariri M., Mirvaghefib A, Farahmandb H, Taghavia L, Shahabiniac A (2018) In situ assessment of Karaj River genotoxic impact with the alkaline comet assay and micronucleus test, on feral brown trout (Salmo trutta fario). Environmental Toxicology and Pharmacology 58: 59-69

[62] Osman AGM, Abuel-Fadl KF, Kloas W (2012) In situ evaluation of the genotoxic potential of the river Nile: II. Detection of DNA strand-breakage and apoptosis in Oreochromis niloticus niloticus (Linnaeus, 1758) and Clarias gariepinus (Burchell, 1822). Mutation Research/Genetic Toxicology and Environmental Mutagenesis 747: 14-21. DOI:10.1016/j. mrgentox.2012.02.013.

[63] Cavas T, Konen S (2007). Detection of cytogenetic and DNA damage in peripheral erythrocytes of goldfish (Carassius auratus) exposed to a glyphosate formulation using the micronucleus test and the comet assay. Mutagenesis, 22, 263-268.

[64] Kushwaha B., Pandey, S., Sharma, S. (2012). In situ assessment of genotoxic and mutagenic potential of polluted river water in Channa punctatus and Mystus vittatus. Int Aquat Res 4, 16 (2012). https://doi.org/10.1186/2008-6970-4-16

[65] Nwani CD, Nagpure NS, Kumar R, Kushwaha B, Lakra WS (2013) DNA damage and oxidative stress modulatory effects of glyphosate-based herbicide in freshwater fish, Channa punctatus. Environmental toxicology and pharmacology (36): 539-547. 
[66] WHO (2003). Background Document for Preparation of WHO Guidelines for Drinking-Water Quality. World Health Organization, Geneva.

\section{Tables}

Due to technical limitations, table 1-4 is only available as a download in the Supplemental Files section.

\section{Figures}

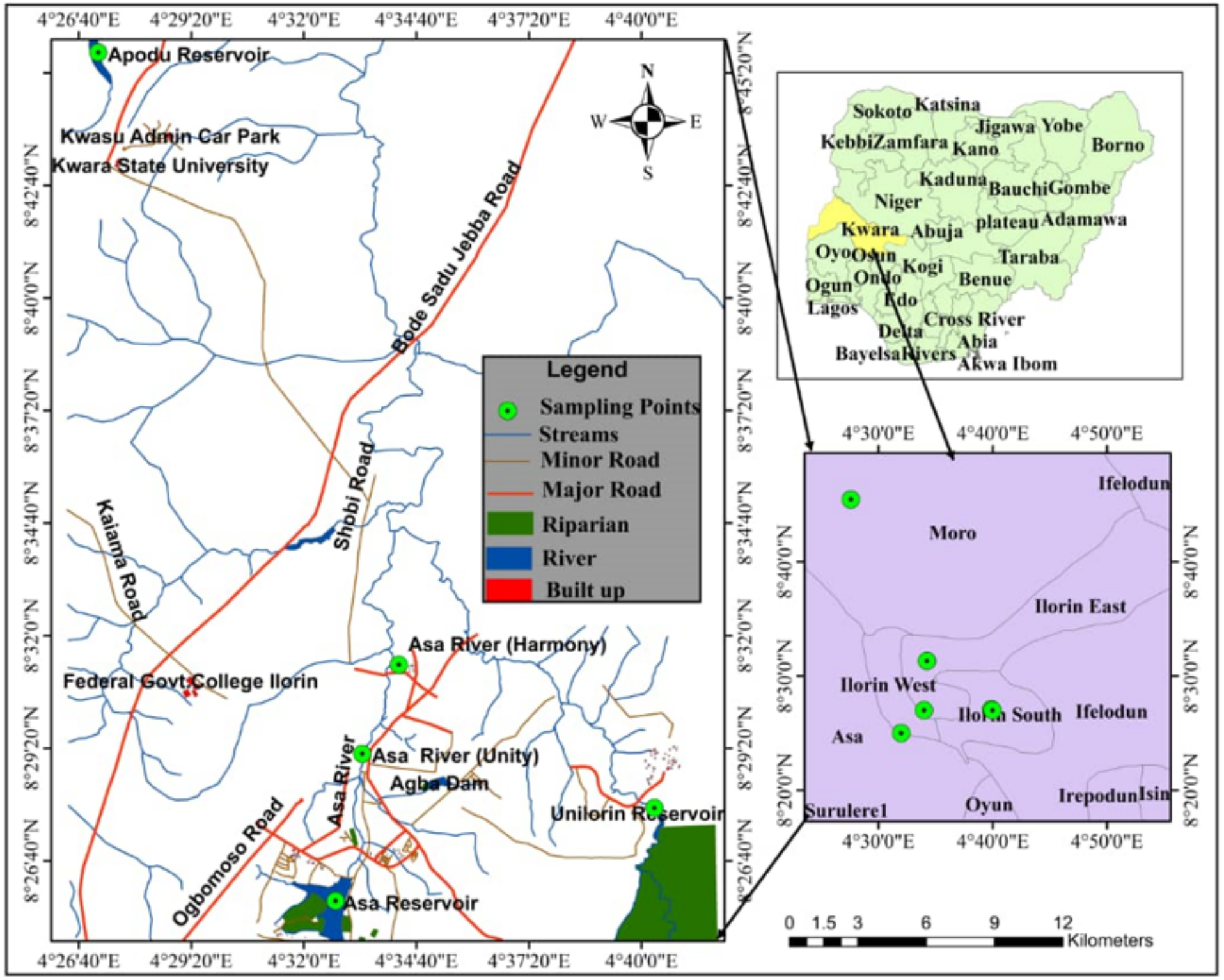

Figure 1

Map of the Study Area showing the Sampling points (Green circle). 

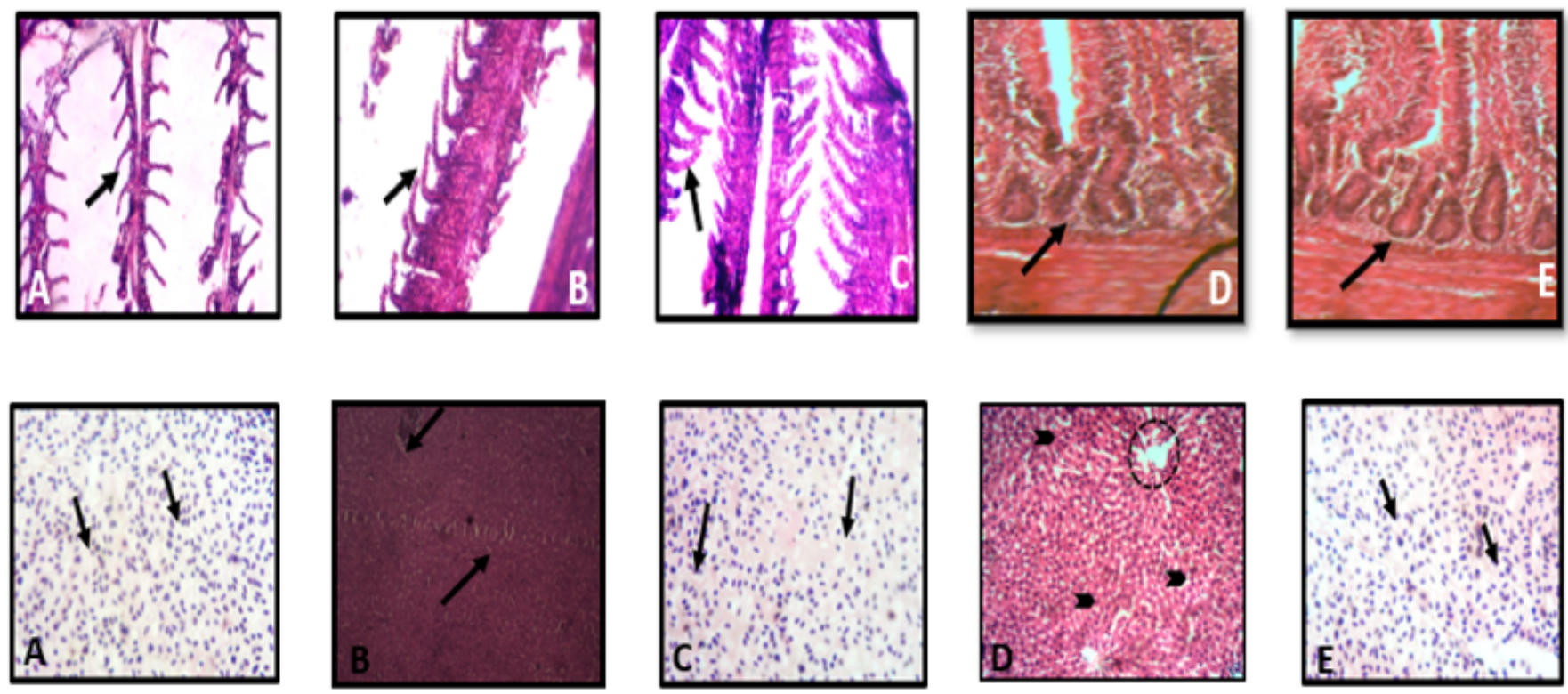

Figure 2

I: Histopathological Analysis of the gills of Tilapia zillii across the five sampling sites. Mag x $100 \mathrm{~A}$. Unilorin reservoir: shows a high-power magnification of the highly vascularized gill arch and outgrowing lamellae B. Apodu reservoir: shows a high-power magnification of the highly vascularized gill arch and their adjoining primary and secondary lamellae. It appears normal with long and well vascularized lamellar system with no pathological alteration. C. Asa reservoir: shows highly vascularized gill arch and out growing lamellae with no signs of pathological alterations. The primary lamellae appear short and supported in the central part by a cartilage with appreciable vascular supply D. Asa river (Unity): shows pathological alteration in the secondary lamella as they appear to be degenerating, distorted cartilage with epithelial lining E. Asa river (Harmony): shows the gill arch and their adjoining primary and secondary lamellae. It appears distorted with as in the gill arch and perturbation of gill filaments which appear to be degenerating and distorted. II: Histopathological Analysis of the Liver of Tilapia zillii across the five sampling sites. Mag x100 A. Unilorin reservoir: shows densely exhibited hepatocytes nuclei (black arrows) with normal staining characteristics and cellular disposition. Their general histomorphology appear characteristically normal with no apparent pathological alteration B. Apodu reservoir: shows mild distortion of hepatic tissue with interstitial congestion scan. C. Asa reservoir: shows densely distributed hepatocyte nuclei (black arrow) The micrograph appears characteristically normal with typical staining intensity and normal histoarchitectural manifestation D. Asa river (Unity): the photomicrograph shows the central vein (black outline) and a high magnification of the hepatocytes (black head arrow) revealing the disposition of the nuclei, staining intensity and general histomorphological presentation.

Histomorphological presentation of the liver showing typically sized halo spaced central vein surrounded by densely distributed hepatocytes E. Asa river (Harmony): the T. zilllii liver shows densely distributed 
hepatocyte nuclei (black arrow). The micrograph appears characteristically normal with typical staining intensity and normal histoarchitectural manifestation.

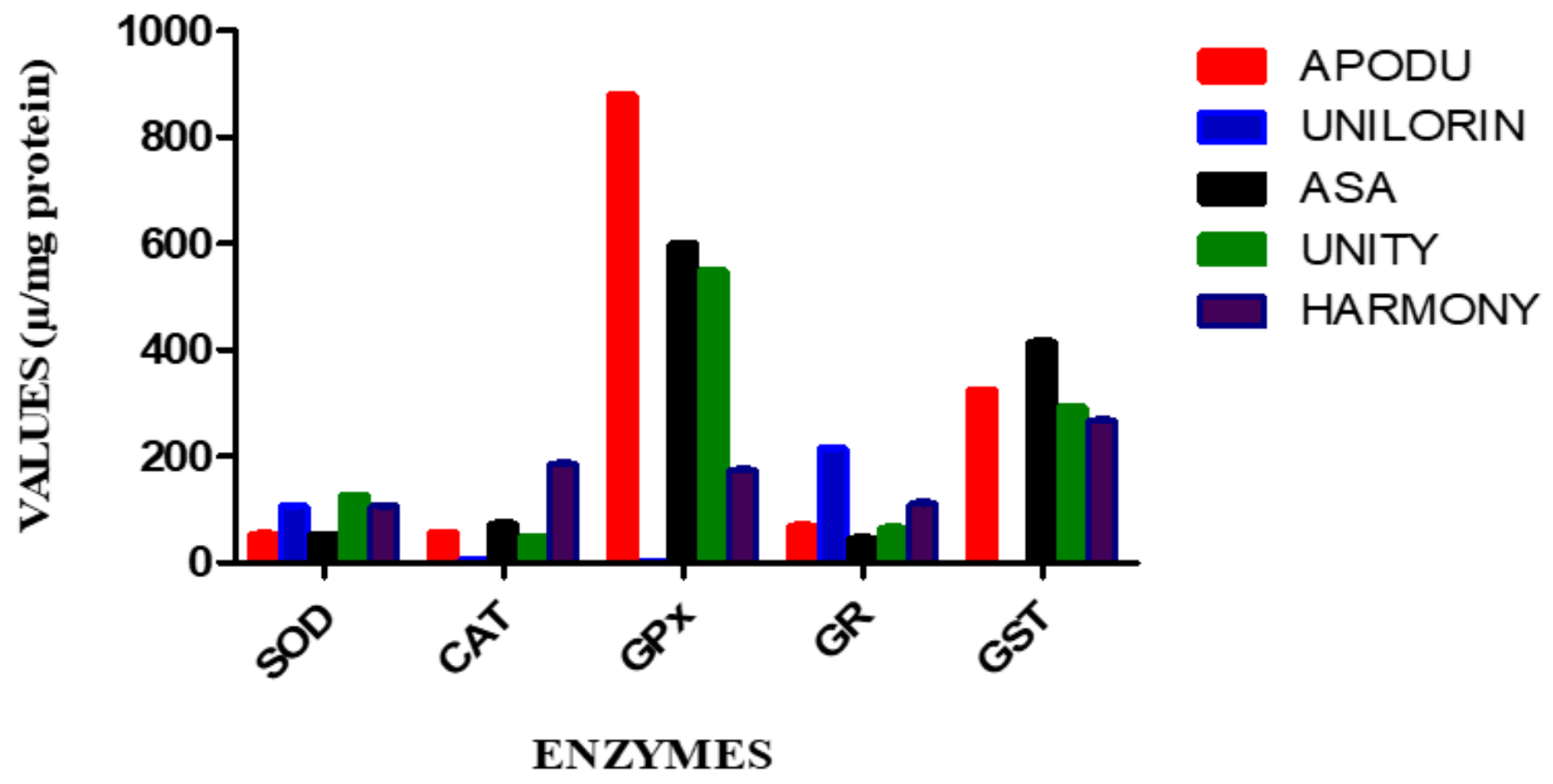

Figure 3

Antioxidant enzyme activities induced in T. zillii across the five sampling sites. 

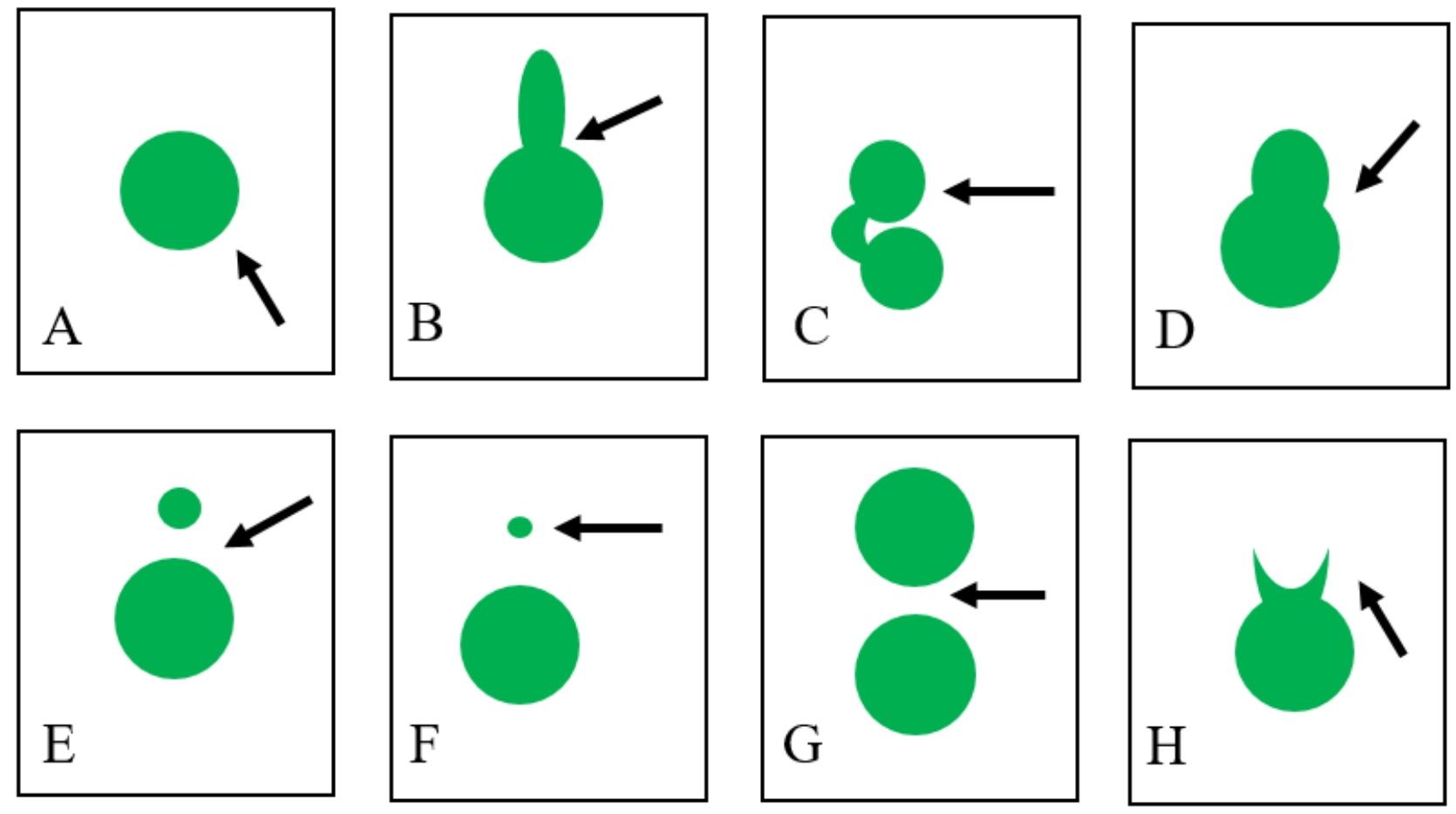

\section{a}
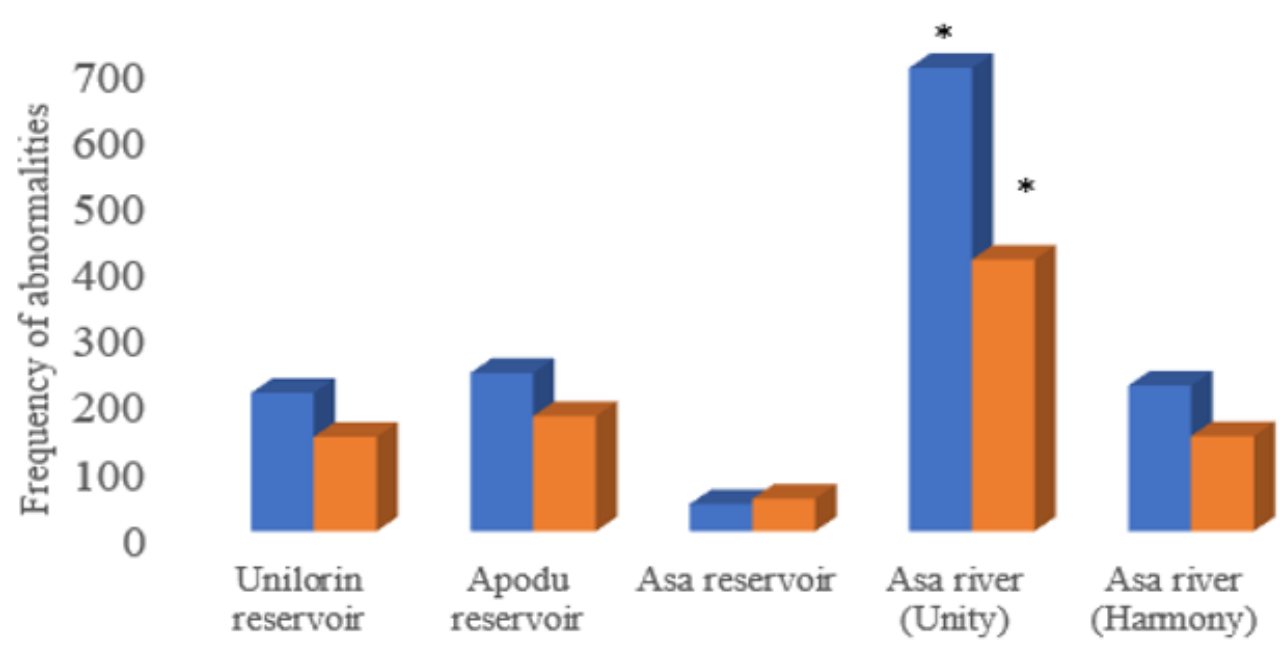

b

Water Sampling locations

$\square$ T. zillii $\square$ C. gariepinus

\section{Figure 4}

a: Various micronuclei and Nuclear abnormalities observed $A=$ Normal nucleus $D=$ Nuclear bud; $E \& F=$ Micronucleus; $\mathrm{G}=$ Binucleated; $\mathrm{H}$ = Notched ; $\mathrm{B}=$ Blebbed nucleus; $\mathrm{C}=$ Lobed nucleus $\mathrm{b}$ : Micronuclei induction and nuclear abnormalities observed in different species of fish present at the various sites per 2000 cells. 

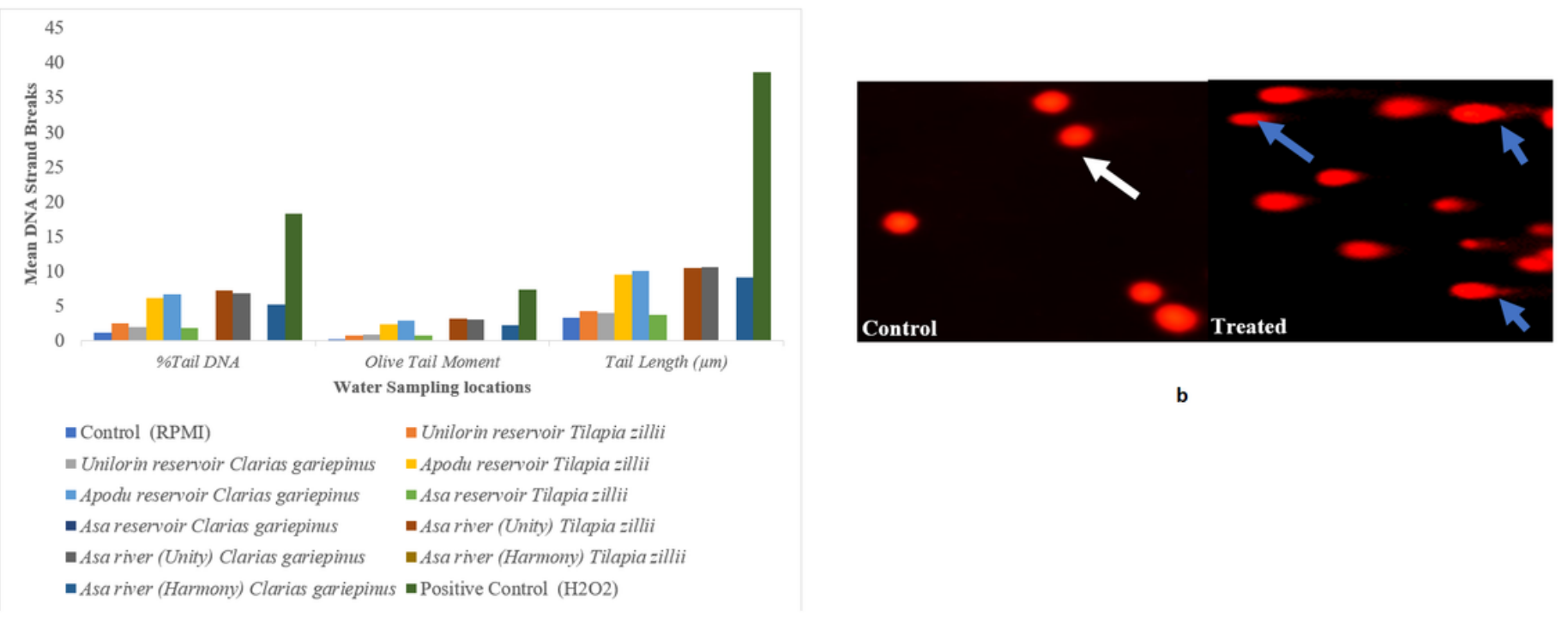

b

a

\section{Figure 5}

a: Mean DNA strand breaks in Clarias gariepinus and Tilapia zillii induced by the sampling water b: Cellular DNA damage Control showing normal shape of a nucleus without comet tail (white arrow) Treated showing abnormal shape of a nucleus with comet tail (blue arrow)

\section{Supplementary Files}

This is a list of supplementary files associated with this preprint. Click to download.

- Tables.pdf 